\title{
Checks Crane Hooks
}

\section{Miroslav Blatnický}

Faculty of Mechanical Engineering, University of Žilina. Univerzitná 8215/1, 01026 Žilina. Slovak Republic. e-mail: miroslav.blatnicky@fstroj.uniza.sk

Paper deals with comparasion of methods for resolving stress state on the example of forged crane hook of selected load. For suitability of the comparasion is necessary to achieve comparable stress values by different methods. Problem of solving of different assignments by different methods is very extensive, and because of it, there is not clear answer, which of methods is universal and so always optimal. Any factors, that enter to the calculation and influence it, is the best way to choose an optimal method for solving of strength problems in mechanics.

Keywords: Crane hook, FEM analysys, Analytical and graphical methods.

\section{Acknowledgement}

This paper was created during the processing of the project No. APVV-0842-11: “Equivalent railway operation load simulator on the roller rig". The work is also supported by the Scientific Grant Agency of the Ministry of Education of the Slovak Republic and the Slovak Academy of Sciences in project No. 1/0347/12: "Railway wheel tread profile wear research under the rail vehicle in operation conditions simulation on the test bench.", project No. 1/0383/12: “The rail vehicle running properties research with the help of a computer simulation." and No. 1/1098/11: "Stress Distribution in a Braked Railway Wheel”.

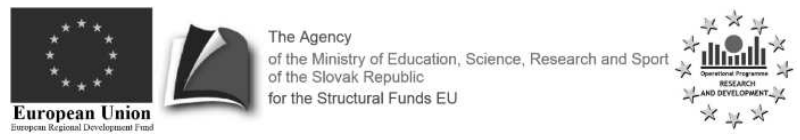

This paper was published with the financial support of the European Union. „We support research activities in Slovakia / Project is co-financed from EU sources"

ITMS 26220220070

\section{References}

[1] DIŽO, J., GERLICI, J., LACK, T. (2011). State of the art tools for railway vehicles systems dynamical analysis performance. In: TRANSCOM 2011 : 9-th European conference of young research and scientific workers : Žilina, June 27-29, 2011, Slovak Republic. - Žilina: University of Žilina, 2011. - ISBN 978-80-554-0375-5. - S. 35-38.

[2] HARUŠINEC, J., ŠŤASTNIAK, P., DIŽO, J. (2013). Výpočty a simulácie pri vývoji konštrukcií kol'ajových vozidiel. In: Technológ : časopis pre teóriu a prax mechanických technológií. - ISSN 1337-8996. - Roč. 5, č. 3 (2013), s. 239-244.

[3] KLEPŠ, Z., NOŽIČKA, J. (1986). Technické tabulky. STNL Praha. 04-230-86.

KOŠÁBEK, J. (1990). Teória dopravných a manipulačných zariadení. Alfa Bratislava. ISBN 80-05-00494-X. 